\title{
Evaluation of antioxidant activity and toxicity in Artemia salina of the ether extract and fractions from Tecoma stans seeds
}

\author{
Avaliação da atividade antioxidante e toxicidade em Artemia salina do extrato etéreo e frações de
} sementes de Tecoma stans

Evaluación de la actividad antioxidante y la toxicidad en Artemia salina a partir de extracto etéreo y fracciones de semillas de Tecoma stans

Received: 07/02/2021 | Reviewed: 07/10/2021 | Accept: 07/12/2021 | Published: 07/22/2021

Lucas Santos Azevedo

ORCID: https://orcid.org/0000-0002-1220-3724 Universidade Federal de São João del Rei, Brazil E-mail: azevedolucas@outlook.com

Thaís Paula Rodrigues Gonçalves ORCID: https://orcid.org/0000-0001-8409-5956 Universidade Federal de São João del Rei, Brazil E-mail: thaispaula.rgs@gmail.com

Paula Avelar Amado

ORCID: https://orcid.org/0000-0001-9192-1849 Universidade Federal de São João del Rei, Brazil E-mail: paulaavelar28@yahoo.com.br

Luciana Alves Rodrigues dos Santos Lima ORCID: https://orcid.org/0000-0002-4130-0304 Universidade Federal de São João del Rei, Brazil E-mail: luarsantos@ufsj.edu.br

\begin{abstract}
Tecoma stans (L.) Juss. Ex Kunth is a species belonging to the Bignoniaceae family, popularly known as yellowing, yellow bell, and garden little ipe. Studies with $T$. stans seeds are scarce and it have potential in the search for natural compounds with biological activities. This study aimed to evaluate the toxicity and antioxidant activity of the ether extract (EE) and fractions from T. stans seeds. The EE was obtained in Soxhlet apparatus with petroleum ether and fractions were obtained by hydrolysis and esterification reactions. Phytochemical screening evaluated the presence of steroids, triterpenoids, alkaloids, coumarins and anthraquinones in EE. The toxicity was evaluated by the A. salina lethality test and antioxidant activity by DPPH method. It was observed the presence of steroids, triterpenoids and alkaloids in EE, which had no toxicity to A. salina $\left(\mathrm{LC}_{50}>1000 \mu \mathrm{g} / \mathrm{mL}\right)$. The fractions of seeds exhibited toxicity on A. salina. All samples showed antioxidant activity with $\mathrm{EC}_{50}$ between 0.9 and $1.1 \mu \mathrm{g} / \mathrm{mL}$. These results indicated potential applications for $T$. stans seeds.
\end{abstract}

Keywords: Tecoma stans; Secondary metabolites; Antioxidant activity; Brine shrimp.

\section{Resumo}

Tecoma stans (L.) Juss. Ex Kunth é uma espécie pertencente à família Bignoniaceae, popularmente conhecida como amarelinho, sino amarelo e ipezinho de jardim. Estudos com sementes de T. stans são escassos e tem potencial na busca de compostos naturais com atividades biológicas. Este trabalho teve como objetivo avaliar a toxicidade e a atividade antioxidante do extrato etéreo (EE) e frações de sementes de T. stans. EE foi obtido em aparelho de Soxhlet com éter de petróleo e as frações foram obtidas por reações de hidrólise e esterificação. A triagem fitoquímica avaliou a presença de esteroides, triterpenoides, alcaloides, cumarinas e antraquinonas no EE. A toxicidade foi avaliada pelo teste de letalidade em A. salina e a atividade antioxidante pelo método de DPPH. Foi observada a presença de esteroides, triterpenoides e alcaloides no EE, que não apresentou toxicidade para A. salina $\left(\mathrm{CL}_{50}>1000 \mu \mathrm{g} / \mathrm{mL}\right)$. As frações do EE das sementes de T. stans exibiram toxicidade em A. salina. Todas as amostras apresentaram atividade antioxidante com $\mathrm{CE}_{50}$ entre 0,9 e $1,1 \mu \mathrm{g} / \mathrm{mL}$. Esses resultados indicam potenciais aplicações para sementes de $T$. stans.

Palavras-chave: Tecoma stans; Metabólitos secundários; Atividade antioxidante; Artemia salina.

\section{Resumen}

Tecoma stans (L.) Juss. Ex Kunth es una especie perteneciente a la familia Bignoniaceae, popularmente conocida como amarillamiento, campana amarilla y ipezito de jardín. Los estudios con semillas de $T$. stans son escasos y tienen 
potencial en la búsqueda de compuestos naturales con actividades biológicas. Este trabajo tuvo como objetivo evaluar la toxicidad y actividad antioxidante del extracto etéreo (EE) y fracciones de semilla de T. stans. El EE se obtuvo en un aparato Soxhlet con éter de petróleo y las fracciones se obtuvieron mediante reacciones de hidrólisis y esterificación. El cribado fitoquímico evaluó la presencia de esteroides, triterpenoides, alcaloides, cumarinas y antraquinonas en EE. La toxicidad se evaluó mediante la prueba de letalidad en A. salina y la actividad antioxidante mediante el método DPPH. En el EE se observó la presencia de esteroides, triterpenoides y alcaloides, los cuales no mostraron toxicidad para $A$. salina $\left(\mathrm{CL}_{50}>1000 \mu \mathrm{g} / \mathrm{mL}\right)$. Las fracciones de EE de las semillas de T. stans mostraron toxicidad en A. salina. Todas las muestras mostraron actividad antioxidante con $\mathrm{CE}_{50}$ entre $0.9 \mathrm{y} 1.1 \mu \mathrm{g} / \mathrm{mL}$. Estos resultados indicaron aplicaciones potenciales para las semillas de T. stans.

Palabras clave: Tecoma stans; Metabolitos secundarios; Actividad antioxidante; Camarón de salmuera.

\section{Introduction}

Tecoma stans (L.) Juss. Ex Kunth is a species belonging to the Bignoniaceae family, popularly known as yellowing, yellow bell and garden little ipe (Kranz \& Passini, 1997). This species exhibits antibacterial, antioxidant, antinociceptive, antiinflammatory, antidiabetic and larvicidal activities; and these effects are correlated to presence of alkaloids, anthraquinones, phenolic compounds, steroids, glycosides, hydrocarbons, essential oils, tannins, terpenes and saponins (Alonso-Castro et al., 2010; Prasanna et al., 2013; Salem et al., 2013). Studies with T. stans seeds are scarce and it have potential in the search for natural compounds with biological activities.

An important problem that concerns researchers are diseases caused by the uncontrolled production of free radicals. Many diseases, such as cardiovascular diseases, cancer, Alzheimer's and cataracts, are correlated to excess free radicals in the body (Neha et al., 2019; Pohanka, 2018). Various plants have polyunsaturated fatty acids (omega 3 and omega 6) and carotenoids, which may be applicable in the treatment of diseases associated with oxidative stress, that promote lipid peroxidation, damage to DNA, enzymes and proteins (Martin et al., 2006; Simopoulos, 2002).

Due to the scarcity of studies that prove the biological potential of plants used by the population, it is necessary to evaluation for the toxicological activity of these extracts to ensure their safe use. Tests with A. salina allow the assessment with sensitivity, being an indicative model of toxicity for animal species that make up the ecosystem (Favilla et al., 2006).

Thus, the objective of this work was to evaluate the antioxidant activity and toxicity of the ether extract and fractions from T. stans seeds.

\section{Methodology}

This work is an experimental research with a quantitative approach (Pereira et al., 2018), carried by data collection through the use of measurements of values, being the application of this method necessary to verify the results obtained from the objectives proposed.

\subsection{Chemicals}

Petroleum ether, methanol $\left(\mathrm{CH}_{3} \mathrm{OH}\right)$, potassium hydroxide $(\mathrm{KOH})$, hydrochloric acid $(\mathrm{HCl})$, sulfuric acid $\left(\mathrm{H}_{2} \mathrm{SO}_{4}\right)$, anhydrous sodium sulfate $\left(\mathrm{Na}_{2} \mathrm{SO}_{4}\right)$ and hexane $\left(\mathrm{C}_{6} \mathrm{H}_{14}\right)$ were purchased from Dinâmica ${ }^{\circledR}$ (Brazil); 2,2-diphenyl-1-picrylhydrazine (DPPH) and dimethylsulfoxide (DMSO) were obtained from Sigma-Aldrich ${ }^{\circledR}$ (Germany); 2,6-di-tert-butyl-4-methyl phenol (BHT) was purchased from Merck ${ }^{\circledR}$ (Germany); Artemia salina eggs and synthetic sea salt were purchased from $\operatorname{Maramar}^{\circledR}\left(\right.$ Brazil) and Marinemix ${ }^{\circledR}$ (Brazil), respectively.

\subsection{Plant material}

The plant material was collected in a Cerrado area located in Divinópolis, Minas Gerais State (20¹0'44'’S latitude and longitude 4455'6" W GRW). The vouchers were identified as Tecoma stans (L) Juss. Ex Kunth by Andréia Fonseca Silva 
and deposited in the PAMG Herbarium, belonging to the Minas Gerais Agricultural Research Corporation (EPAMIG), under registration number 58284. This study has access permission to the components of plant genetic heritage and it is registered in the SisGen Platform (Register AEF6C95), according to Brazilian Biodiversity Law (13.123/2015).

\subsection{Obtaining extract and fractions}

To obtain ether extract (EE), the plant material was exhaustively extracted with petroleum ether at $40{ }^{\circ} \mathrm{C}$ in the Soxhlet apparatus for 40 cycles. For hydrolyzed fatty acids (FA), the ether extract was solubilized in $\mathrm{KOH}(1 \mathrm{~mol} / \mathrm{L})$ solution and kept under reflux for 30 minutes. After cooling, the solution was acidified with $1 \mathrm{~mol} / \mathrm{L}$ hydrochloric acid $(\mathrm{HCl})$ and extracted with hexane, which was removed in a rotary evaporator (Ika RV10). To obtain the fatty acids methyl esters (FAME), the fatty acids were solubilized in hexane, a $2 \% \mathrm{v} / \mathrm{v}$ methanolic solution of sulfuric acid $\left(\mathrm{H}_{2} \mathrm{SO}_{4}\right)$ was added, which was kept under reflux for 1 hour. After cooling, the organic phase obtained with the addition of saturated sodium chloride solution $(\mathrm{NaCl})$, and the hexane was removed in a rotary evaporator (Ika RV10) (Silva et al., 2015).

\subsection{Phytochemical screening}

Steroids and triterpenoids presence was evaluated by Lieberman-Burchard reaction, alkaloids by Dragendorff reaction and coumarins and anthraquinones by the addition of $\mathrm{NaOH}(1 \mathrm{~mol} / \mathrm{L}$ ) (Matos, 2009).

\subsection{Evaluation of antioxidant activity}

The antioxidant activity was evaluated by DPPH scavenging test (Brand-Williams, Cuvelier \& Berset, 1995), with modifications (Araújo et al., 2013). Exactly $75 \mu \mathrm{L}$ of the samples $(1,10,100,250$, and $500 \mu \mathrm{g} / \mathrm{mL}$ ) and $150 \mu \mathrm{L}$ of the DPPH $(0.0002 \% \mathrm{v} / \mathrm{v})$ solution were added in a 96 -well plate and maintained at $25{ }^{\circ} \mathrm{C}$ for 30 minutes. The reading was made on a spectrophotometer (Power Wave XS2, $\lambda=517 \mathrm{~nm}$ ). The experiment was done in triplicate. The percentage of antioxidant activity was calculated using the formula: \% inhibition of $\mathbf{D P P H}=[\mathbf{1}-(\mathbf{A a} / \mathbf{A b})] \mathbf{x} \mathbf{1 0 0}$, where $\mathbf{A a}=$ absorbance of the sample and $\mathbf{A b}=$ absorbance of DPPH.

The effective concentration to decolorize $50 \%$ of the DPPH solution $\left(\mathrm{EC}_{50}\right)$ was calculated using the probitos analysis method (Finney, 1980).

\subsection{Artemia salina lethality assay}

Saline water was prepared by adding $38 \mathrm{~g}$ of sea salt in $1 \mathrm{~L}$ of distilled water. A. salina eggs were placed in the solution $(200 \mathrm{mg} / 400 \mathrm{~mL})$ for 48 hours under aeration, being the first four hours under $40 \mathrm{w}$ light. Then, 10 nauplii were collected and transferred to test tubes with the samples (1000, 500, 250 and $125 \mu \mathrm{g} / \mathrm{mL})$ and DMSO $(1,0.5,0.25$ and $0.125 \%)$. The nauplii were counted with the aid of a magnifying glass after 24 hours of treatment with samples (Pimenta et al., 2003) and the Lethal Concentration capable of killing 50\% ( $\left.\mathrm{LC}_{50}\right)$ and $90 \%\left(\mathrm{LC}_{90}\right)$ was calculated by the probit analysis method (Finney, 1980).

\section{Results and Discussion}

\subsection{Phytochemical screening}

The presence of steroids, triterpenoids and alkaloids was observed in EE, which corroborates with the literature. The monoterpene alkaloids (tecomine and tecostanin), 5- $\beta$-hydroxyskitantine and boschniakina have already been identified in $T$. stans seeds and leaves (Costantino et al., 2003). Gonçalves, Parreira \& Lima (2020) also related the presence of alkaloids and steroids in hexane fraction from flowers. 


\subsection{Evaluation of antioxidant activity}

As shown in Table 1, the EE and FA exhibited antioxidant activity greater than 50\% in all concentrations evaluated. The samples, at concentrations of 1 and $10 \mu \mathrm{g} / \mathrm{mL}$, were more efficient in capturing the DPPH radical than the positive control $\mathrm{BHT}$, with small values of $\mathrm{EC}_{50}$.

Table 1. DPPH scavenging activity and $\mathrm{EC}_{50}$ values of ether extract and fractions from Tecoma stans seeds.

\begin{tabular}{ccccccc}
\hline \multirow{2}{*}{ Samples } & \multicolumn{5}{c}{ DPPH-scavenging activity } & \multirow{2}{*}{ EC $\mathbf{5 0}(\boldsymbol{\mu g} / \mathbf{m L})^{\mathbf{1}}$} \\
\cline { 2 - 6 } & $\mathbf{1} \boldsymbol{\mu \mathbf { g } / \mathbf { m L }}$ & $\mathbf{1 0} \boldsymbol{\mu \mathbf { g } / \mathbf { m L }}$ & $\mathbf{1 0 0} \boldsymbol{\mu g} / \mathbf{m L}$ & $\mathbf{2 5 0} \boldsymbol{\mu g} / \mathbf{m L}$ & $\mathbf{5 0 0} \boldsymbol{\mu g} / \mathbf{m L}$ & \\
\cline { 2 - 6 } EE & $51.96 \pm 0.82^{*}$ & $52.75 \pm 0.82^{*}$ & $55.92 \pm 0.23^{*}$ & $58.03 \pm 1.50^{*}$ & $65.69 \pm 0.79^{*}$ & $0.92 \pm 0.07^{*}$ \\
FA & $51.17 \pm 0.60^{*}$ & $53.15 \pm 0.60^{*}$ & $54.21 \pm 0.68^{*}$ & $55.66 \pm 0.60^{*}$ & $59.62 \pm 4.92^{*}$ & $0.91 \pm 0.08^{*}$ \\
FAME & $49.85 \pm 0.39^{*}$ & $50.38 \pm 2.32^{*}$ & $51.43 \pm 2.20^{*}$ & $52.62 \pm 1.81^{*}$ & $55.53 \pm 0.99^{*}$ & $1.03 \pm 0.10^{*}$ \\
BHT & $18.5 \pm 0.14$ & $25.58 \pm 0.28$ & $86.51 \pm 0.61$ & $91.37 \pm 0.16$ & $94.19 \pm 0.37$ & $16.36 \pm 1.63^{*}$ \\
\hline
\end{tabular}

Ether extract (EE), fatty acids (FA), fatty acids methyl esters (FAME), 2,6-di-tert-butyl-4-methylphenol (BHT). ${ }^{1}$ EC50: Effective concentration (in $\mu \mathrm{g} / \mathrm{mL}$ ) of sample required to inhibit the formation of DPPH radicals by 50\%. *: Statistically significant $(p<0.05)$ compared to BHT. The results were expressed in means \pm SE $(n=3)$. Source: Authors.

No works were found for the antioxidant activity of $T$. stans seeds, so our results were compared with studies from other parts of the plant. The samples of flowers showed $\mathrm{EC}_{50}$ values of 3.76 and $2.99 \mu \mathrm{g} / \mathrm{mL}$ for the ethanol extract and the dichloromethane fraction, respectively (Gonçalves, 2020). The fruits extract obtained with water/ethanol (1:4), under reflux at $70{ }^{\circ} \mathrm{C}$, presented inhibition concentration $\left(\mathrm{IC}_{50}\right)$ of $12.7 \mu \mathrm{g} / \mathrm{mL}$ (Marzouk et al., 2006). These results indicate that the increase in temperature does not influence the antioxidant activity (Simões et al., 2007).

Dry leaves extract, obtained by percolation with water/ethanol (1:1), and the fractions of petroleum ether, ethyl acetate and methanol showed antioxidant activity, being hydroethanolic extract the most active, with $64.32 \%$ of DPPH inhibition (Larbie, Nyarkoh \& Adjei, 2019). Leaves and branches extracts obtained by maceration exhibited IC $_{50}$ values between 10 and $100 \mu \mathrm{g} / \mathrm{mL}$ (Larbie, Nyarkoh \& Adjei, 2019; Salem et al., 2013). The results obtained for the seeds were more promising than for the other plant parts.

The antioxidant activity of EE may be related to secondary metabolites observed. The cyclic carbons together with conjugated double bonds in steroids and terpenes make them potential reducing agents, because they can capture and stabilize Reactive Oxygen Species (ROS) and Reactive Nitrogen Species (RNS) from the environment. Nitrogen atoms in alkaloids molecules have free electron pairs that can also stabilize ROS and RNS. The steroidal alkaloids presented high antioxidant potential (Cerqueira, de Medeiros \& Augusto, 2007; Simões et al., 2007).

The antioxidant activity of FA and FAME of $T$. stans corroborates with the literature. FAME obtained from the seeds of Annona cornifolia (Annonaceae) presented $\mathrm{IC}_{50}=3.83 \mu \mathrm{g} / \mathrm{mL}$ (Lima et al., 2012), as well as FAME from commercial soy, corn and sunflower oils exhibited $\mathrm{IC}_{50}$ values between 1 and $10 \mu \mathrm{g} / \mathrm{mL}$ (Pinto et al., 2017). A study with FA and FAME of leaves of $S$. brasiliensis showed $\mathrm{IC}_{50}$ values $<1 \mu \mathrm{g} / \mathrm{mL}$ (Amado et al., 2018).

\subsection{Artemia salina lethality assay}

As shown in Table 2, the EE promoted low mortality of A. salina in all concentrations, causing lethality below $20 \%$ in the highest concentration tested. FA caused mortality below $50 \%$ at concentration of $500 \mu \mathrm{g} / \mathrm{mL}$; however, at concentration of 1000 , the mortality was $91.11 \%$. FAME exhibited mortality higher than $50 \%$ in all concentrations evaluated. 
Table 2. A. salina letality, $\mathrm{LC}_{50}$ and $\mathrm{LC}_{90}$ values of ether extract and fractions from Tecoma stans seeds.

\begin{tabular}{|c|c|c|c|c|c|c|}
\hline \multirow{2}{*}{ Samples } & \multicolumn{4}{|c|}{ Artemia salina letality } & \multirow{2}{*}{$\begin{array}{c}\text { LC }_{50} \\
(\mu \mathrm{g} / \mathrm{mL})^{1}\end{array}$} & \multirow{2}{*}{$\begin{array}{c}\mathbf{L C}_{90} \\
(\boldsymbol{\mu g} / \mathbf{m L})^{2}\end{array}$} \\
\hline & $125 \mu \mathrm{g} / \mathrm{mL}$ & $250 \mu \mathrm{g} / \mathrm{mL}$ & $500 \mu \mathrm{g} / \mathrm{mL}$ & $1000 \mu \mathrm{g} / \mathrm{mL}$ & & \\
\hline $\mathbf{E E}$ & $0.00 \pm 0.00$ & $2.22 \pm 0.96^{\mathrm{a}}$ & $4.44 \pm 1.36^{\mathrm{a}}$ & $8.88 \pm 2.25^{\mathrm{b}}$ & N.D. & N.D. \\
\hline FA & $16.65 \pm 2.96^{\mathrm{a}}$ & $28.86 \pm 3.67^{\mathrm{b}}$ & $38.33 \pm 4.19^{\mathrm{b}}$ & $95.46 \pm 2.27^{\mathrm{c}}$ & 486.27 & 1180.94 \\
\hline FAME & $67.71 \pm 1.38^{\mathrm{a}}$ & $88.80 \pm 2.63^{\mathrm{b}}$ & $98.86 \pm 1.41^{\mathrm{c}}$ & $100.00 \pm 0.00^{\mathrm{c}}$ & 7.52 & 164.63 \\
\hline
\end{tabular}

Ether extract (EE), fatty acids (FA) and fatty acids methyl esters (FAME). ${ }^{1} \mathrm{LC}_{50}$ : Lethal concentration $(\mu \mathrm{g} / \mathrm{mL}) \mathrm{of}$ sample required to kill A. salina by $50 \%$. ${ }^{2} \mathrm{LC} 90$ : Lethal concentration $(\mu \mathrm{g} / \mathrm{mL})$ of sample required to kill A. salina by $90 \%$. The results were expressed in means $\pm \mathrm{SE}(\mathrm{n}=3)$. Means followed by the same letter on the same line do not differ according to the Tukey test $(p<0.05)$. N.D.: not determined. Source: Authors.

A. salina is considered a good model for assessing the toxicity of plant extracts since the results obtained in this assay can be extrapolated to other tests (Pimenta et al., 2003). However, studies with FA and FAME assessing lethality in this model are still scarce.

FAME from A. cornifolia seeds promoted high mortality in A. salina nauplii, with $\mathrm{LC}_{50}=8.77 \mu \mathrm{g} / \mathrm{mL}$ (Lima, 2006). Another study evaluating the lethality of EE, FA and FAME of S. brasiliensis leaves in A. salina, it was observed that FAME exhibited higher lethality $\left(\mathrm{LC}_{50}=681.59 \mu \mathrm{g} / \mathrm{mL}\right)$, followed by FA $\left(\mathrm{LC}_{50}=899.34 \mu \mathrm{g} / \mathrm{mL}\right)$, while FAME did not present considerable toxicity (Amado et al., 2018).

Studies evaluating the activity of $T$. stans on A. salina are even scarce, with only one report in the literature. Thein \& Oo (2019) evaluated the larvicidal activity of aqueous and ethanolic extracts (70\%) from leaves. For the aqueous extract, the concentrations between 187.5 and $3000 \mu \mathrm{g} / \mathrm{mL}$ were tested, with mortality ranging between $7 \%$ and $96 \%$; for the ethanolic extract (70\%), the concentrations were from 250 to $4000 \mu \mathrm{g} / \mathrm{mL}$, with mortality between $3 \%$ and $91 \%$. The $\mathrm{LC}_{50}$ values obtained were $878 \mu \mathrm{g} / \mathrm{mL}$ for the aqueous extract and $1318 \mu \mathrm{g} / \mathrm{mL}$ for the ethanolic extract (70\%). In our study, the $\mathrm{LC}_{50}$ values found for FA and FAME of the seeds demonstrated greater toxicity than the aqueous and ethanol extracts (70\%) of the leaves. Thus, as FA and FAME have $\mathrm{LC}_{50}$ values less than $1000 \mu \mathrm{g} / \mathrm{mL}$, they are considered toxic; while $\mathrm{EE}$ has no toxicity (Meyer et al., 1982).

\section{Final Considerations}

In this study, it can be concluded that EE, FA and FAME from T. stans seeds have antioxidant activity, with potential for future studies. This effect may be related to the presence of steroids, triterpenoids and alkaloids. Among the samples, the EE is safe for the environment, while FA and FAME have toxicological potential.

In order to improve this study, it is interesting to identify the compounds present in EE, FA and FAME, and evaluate their effect in other biological models.

\section{Acknowledgments}

The authors thanks to Universidade Federal de São João del-Rei (UFSJ), Coordenação de Aperfeiçoamento de Pessoal de Nível Superior (CAPES) and Conselho Nacional de Desenvolvimento Científico e Tecnológico (CNPq) for funding and support. "This study was financed in part by the Coordenação de Aperfeiçoamento de Pessoal de Nível Superior - Brasil (CAPES) - Finance Code 001. 


\section{References}

Alonso-Castro, A. J., Zapata-Bustos, R., Romo-Yañez, J., Camarillo-Ledesma, P., Gómez-Sánchez, M. \& Salazar-Olivo, L. A. (2010). The antidiabetic plants Tecoma stans (L.) Juss. ex Kunth (Bignoniaceae) and Teucrium cubense Jacq (Lamiaceae) induce the incorporation of glucose in insulin-sensitive and insulinresistant murine and human adipocytes. Journal of Ethnopharmacology, 127(1), 1-6. https://doi.org/10.1016/j.jep.2009.09.060

Amado, P. A., Ferraz, V., da Silva, D. B., Carollo, C. A., Castro, A. H. F. \& Lima, L. A. R. S. (2018). Chemical composition, antioxidant and cytotoxic activities of extracts from the leaves of Smilax brasiliensis Sprengel (Smilacaceae). Natural Product Research, 32(5), 610-615. https://doi.org/10.1080/14786419.2017.1327861

Araújo, S. G., Pinto, M. E. A., Silva, N. L.; dos Santos, F. J. L., Castro, A. H. F. \& Lima, L. A. R. S. (2013). Antioxidant and allelopathic activities of extract and fractions from Rosmarinus officinalis. Biochemistry and Biotechnology Reports, 2(1), 35-43. https://doi.org/10.5433/2316-5200.2013v2n1p35

Brand-Williams, W., Cuvelier, M. E. \& Berset, C. (1995). Use of a free radical method to evaluate antioxidant activity. LWT - Food Science and Technology, 28(1), 25-30. https://doi.org/10.1016/S0023-6438(95)80008-5

Cerqueira, F. M., de Medeiros, M. H. G. \& Augusto, O. (2007). Dietetic antioxidants: controversies and perspectives. Química Nova, 30(2), 441-449. https://doi.org/10.1590/S0100-40422007000200036

Costantino, L., Raimondi, L., Pirisino, R., Brunetti, T., Pessotto, P., Giannessi, F., Lins, A. P., Barlocco, D., Antolini, L. \& El-Abady, S. A. (2003). Isolation and pharmacological activities of the Tecoma stans alkaloids. Farmaco, 58(9), 781-785. https://doi.org/10.1016/S0014-827X(03)00133-2

Favilla, M., Macchia, L., Gallo, A. \& Altomare, C. (2006). Toxicity assessment of metabolites of fungal biocontrol agent using two different (Artemia salina and Daphnia magna) invertebrate bioassays. Food and Chemical Toxicology, 44(11), 1922-1931. https://doi.org/10.1016/j.fct.2006.06.024

Finney, D. J. (1980). Probit analysis, a statistical treatment of the sigmoid response curve. University Press.

Gonçalves, T. P. R., Parreira, A. G. \& Lima, L. A. R. S. (2020). Study of the antimicrobial activity of Tecoma stans (L.) ex Kunth (Bignoniaceae). Tchê Química, 18(35), 1037-1043.

Gonçalves, T. P. R. (2020). Estudo fitoquímico e avaliação do potencial antimicrobiano, sinérgico e antioxidante das flores de Tecoma stans (L.) Juss. ex Kunth (Bignoniaceae). Master Dissertation, Federal University of São João del-Rei, Divinópolis, MG, Brazil.

Kranz, W. M. \& Passini, T. (1997). Amarelinho: biologia e controle. Instituto Agronômico do Paraná.

Larbie, C., Nyarkoh, C. O. \& Adjei, C.O. (2019). Phytochemical and safety evaluation of hydroethanolic leaf extract of Tecoma stans (L.) Juss. ex Kunth. Evidence-Based Complementary and Alternative Medicine, 2019, 1-12. https://doi.org/10.1155/2019/7417624

Lima, L. A. R. S. (2006). Estudo químico e avaliação biológica das sementes de Annona cornifolia A. St. -Hil. (Annonaceae). Doctoral Thesis, Federal University of Minas Gerais, Belo Horizonte, MG, Brazil.

Lima, L. A. R. S., Alves, T. M. A., Zani, C. L., Pimenta, L. P. S. \& Boaventura, M. A. D. (2012). Antioxidant and cytotoxic potential of fatty acid methyl esters from the seeds of Annona cornifolia A. St. -Hil. (Annonaceae). Food Research International, $48(2)$, 873-875. https://doi.org/10.1016/j.foodres.2012.07.016

Martin, C. A., de Almeida, V. V., Ruiz, M. R., Visentainer, J. E. L., Matshushita, M., de Souza, N. E. \& Visentainer, J. V. (2006). Omega-3 and omega-6 polyunsaturated fatty acids: importance and occurrence in foods. Revista de Nutrição, 19(6), 761-770. https://doi.org/10.1590/S1415-52732006000600011

Marzouk, M. S. A., Gamal-Eldeen, A. M., Mohamed, M. A. \& El-Sayed, M. M. (2006). Antioxidant and anti-proliferative active constituents of Tecoma stans against tumor cell lines. Natural Product Communications, 1(9), 735-743. https://doi.org/10.1177/1934578X0600100908

Matos, F. J. A. (2009). Introdução a fitoquímica experimental, Edições UFC.

Meyer, B. N., Ferrigni, N. R., Putnam, J. E., Jacobsen, L. B., Nichols, D. E. \& McLaughlin, J. L. (1982). Brine shrimp: a convenient general bioassay for active plant constituents. Planta Medica, 45(5), 31-34. https://doi.org/10.1055/s-2007-971236

Neha, K., Haider, M. R., Pathak, A. \& Yar, M. S. (2019). Medicinal prospects of antioxidants: A review. European Journal of Medicinal Chemistry, 178, 687704. https://doi.org/10.1016/j.ejmech.2019.06.010

Pereira, A. S., Shitsuka, D. M., Parreira, F. J. \& Shitsuka, R. (2018). Metodologia da pesquisa científica[e-book]. UAB/NTE/UFSM. Avaliable: https://repositorio. ufsm. br/bitstream/handle.

Pimenta, L. P. S., Pinto, G. B., Takahashi, J. A., Silva, L. G. F. E. \& Boaventura, M. A. D. (2003). Biological screening of Annonaceous Brazilian medicinal plants using Artemia salina (Brine Shrimp Test). Phytomedicine, 10(2-3), 209-212. https://doi.org/10.1078/094471103321659960

Pinto, M. E. A., Araújo, S. G., Morais, M. I., Sá, N. P., Lima, C. M., Rosa, C. A., Siqueira, E. P., Johann, S. \& Lima, L. A. R. S. (2017). Antifungal and antioxidant activity of fatty acid methyl esters from vegetable oils. Anais da Academia Brasileira de Ciências, 89(3), 1671-1681. https://doi.org/10.1590/00013765201720160908

Pohanka, M. (2018). Oxidative stress in Alzheimer disease as a target for therapy. Bratislava Lek Listy, 119(9), 535-543. https://doi.org/10.4149/BLL_2018_097

Prasanna, V. L., Lakshman, K., Hegde, M. M. \& Bhat, V. (2013). Antinociceptive and anti-inflammatory activity of Tecoma stans leaf extracts. Indian Journal of Research in Pharmacy and Biotechnology, 1(2), 156-160. 
Research, Society and Development, v. 10, n. 9, e12510917829, 2021

(CC BY 4.0) | ISSN 2525-3409 | DOI: http://dx.doi.org/10.33448/rsd-v10i9.17829

Salem, M. Z. M., Gohar, Y. M., Camacho, L. M., El-Shanhorey, N. A. \& Salem, A. Z. M. (2013). Antioxidant and antibacterial activities of leaves and branches extracts of Tecoma stans (L.) Juss. ex Kunth against nine species of pathogenic bacteria. African Journal of Microbiology Research, 7(5), 418-426. https://doi.org/10.5897/ajmr12.2274

Silva, V. C. B., Ribeiro-Neto, J. A., Alves, S. N. \& Lima, L. A. R. S. (2015). Larvicidal activity of oils, fatty acids, and methyl esters from ripe and unripe fruit of Solanum lycocarpum (Solanaceae) against the vector Culex quinquefasciatus (Diptera: Culicidae). Revista da Sociedade Brasileira de Medicina Tropical, 48(5), 610-613. https://doi.org/10.1590/0037-8682-0049-2015

Simões, C. M. O., Schenkel, E. P., Gosmann, G., De Melo, J. C. P., Mentz, L. A. \& Petrovick, P. R. (2007). Farmacognosia da planta ao medicamento, Editora da UFRGS.

Simopoulos, A. P. (2002). Omega-3 fatty acids in wild plants, nuts and seeds. Asia Pacific Journal of Clinical Nutrition, 11(S6), S163-S173. https://doi.org/10.1046/j.1440-6047.11.s.6.5.x

Thein, A. M. \& Oo, K. C. C. (2019). Phytochemical investigation of Tecoma stans (L.) H. B. K. leaves and its brine shrimp lethality test. 2nd Myanmar Korea Conference Research Journal, 1, 1-11. 